\title{
AMPK - roles in nutrient sensing and in cancer
}

\author{
D Grahame Hardie \\ From Metabolism, Diet and Disease 2014: Cancer and metabolism \\ Washington DC, USA. 28-30 May 2014
}

The AMP-activated protein kinase (AMPK) is a central sensor of cellular energy status. The kinase is activated by increases in cellular AMP by three mechanisms: (i) allosteric activation; (ii) promotion of Thr172 phosphorylation by the upstream kinase LKB1; (iii) inhibition of Thr172 dephosphorylation. Of these, only the third is mimicked by ADP, but all three are antagonized by ATP, thus allowing the system to act as a sensor of cellular energy.

Genes encoding the three subunits of AMPK are found in essentially all eukaryotes, and in unicellular eukaryotes such as Saccharomyces cerevisiae the kinase has a role in sensing and responding to glucose starvation. This cellautonomous role has been preserved in multicellular eukaryotes, but the system has also adapted to respond to hormones involved in regulating whole body energy balance, such as ghrelin, leptin and adiponectin. This suggests that AMPK would be involved in disorders of energy balance, especially insulin resistance. Indeed, AMPK is activated by metformin, currently the first choice drug for treatment of type 2 diabetes. Metformin activates AMPK indirectly by inhibiting the respiratory chain, and does have AMPK-independent effects. However, recent studies suggest that its long-term insulinsensitizing effects are mediated by AMPK activation and consequent effects on lipid metabolism that lower intracellular di- and tri-glycerides.

Findings that the tumor suppressor LKB1 was the upstream kinase phosphorylating Thr172, which is required for AMPK activation by energy stress, introduced a link between AMPK and cancer. Given the importance to cancer of metabolic changes such as increased lipid, protein and RNA synthesis, and the switch from oxidative metabolism to glycolysis (all opposed by AMPK) it seems likely that AMPK exerts some of the tumor suppressor effects of LKB1. One would therefore expect a strong selection pressure for mechanisms that down-regulate AMPK activation. Loss-of-function mutations in LKB1

\footnotetext{
College of Life Sciences, University of Dundee, Dundee, DD1 5EH, Scotland,
} UK

(c) 2014 Hardie; licensee BioMed Central Ltd. This is an Open Access article distributed under the terms of the Creative Commons Attribution License (http://creativecommons.org/licenses/by/4.0), which permits unrestricted use, distribution, and reproduction in any medium, provided the original work is properly cited. The Creative Commons Public Domain Dedication waiver (http:// creativecommons.org/publicdomain/zero/1.0/) applies to the data made available in this article, unless otherwise stated. (found in lung, cervical and skin cancer) is one way this can happen, while reduced expression of AMPK- $\alpha 2$ is also observed in hepatocellular carcinomas. We are currently studying the role of the "ST loop", a serine/threonine-rich region present in the $\mathrm{C}$-terminal domains of all vertebrate AMPK- $\alpha$ subunits. This loop is phosphorylated at multiple sites by growth-associated kinases such as Akt, and this inhibits phosphorylation of Thr172, and hence AMPK activation, by mechanisms that will be discussed. Thus, a previously unrecognized effect of hyper-activation of Akt in tumor cells is that the antagonistic effects of AMPK on cell growth and biosynthesis are reduced.

Published: 28 May 2014

doi:10.1186/2049-3002-2-S1-O16

Cite this article as: Hardie: AMPK - roles in nutrient sensing and in cancer. Cancer \& Metabolism 2014 2(Suppl 1):016.

Submit your next manuscript to BioMed Central and take full advantage of:

- Convenient online submission

- Thorough peer review

- No space constraints or color figure charges

- Immediate publication on acceptance

- Inclusion in PubMed, CAS, Scopus and Google Scholar

- Research which is freely available for redistribution 